\title{
Comparison Study Of Toxicity Bacillus thuringensis from Soil Isolate and Mulberry Leaves in Indonesia
}

\author{
Akhmad Rizali \\ Department of Agroechotechnology, Lambung Mangkurat University, Banjarbaru, Indonesia
}

Email address:

arizali25@yahoo.com

\section{To cite this article:}

Akhmad Rizali. Comparison Study Of Toxicity Bacillus thuringensis from Soil Isolate and Mulberry Leaves in Indonesia. American Journal of Entomology. Vol. 2, No. 1, 2018, pp. 1-5. doi: 10.11648/j.aje.20180201.11

Received: March 30, 2018; Accepted: April 19, 2018; Published: May 9, 2018

\begin{abstract}
Background and Objective: Most strains of $B$. thuringiensis produce delta-endotoxin crystals toxic to lepidopteran insects such moth. But some strains of $B$. thuringiensis produce delta-endotoxin crystals toxic to dipteran insects such as mosquitoes and blackflies. To compare $B$. thuringiensis isolate from soil and mulberry leaves. Material and Methods:One gram of soil samples was suspended in $9 \mathrm{ml}$ of sterile distilled water and shaken for $5 \mathrm{~min}$. the upper layer of the soil suspension was transferred to a test tube and heated at $80^{\circ} \mathrm{C}$ for $5 \mathrm{~min}$ in water bath to kill non-spore-forming organism and vegetative cells to prepare the sporulated culture, bacteria were grown on nutrient agar $\mathrm{pH} 7.2$, at $30^{\circ} \mathrm{C}$ for 4 days. The isolates were obtained from mulberry leaves collected in West Java, Indonesia, using the leaf-lift technique. Leaves were trimmed to fit inside a 100 $\mathrm{mm}$ petri dish. Abaxial leaf surfaces were placed in contact with nutrient agar, and a sterile, per forated stainless steel disk was placed on the leaf sections to ensure maximum contact with the agar. After the sample was coated with carbon and gold, it was observed and photographed with (SEM). However they had differences form crystal protein, but they had unique as insecticidal to control the same orders (mosquitocidal). Results:The study found that B. thuringiensis serovar entomocidus INA288 produced large cuboidal-form crystals and B. thuringiensis serovar aizawai BUN 1-14 a little homology with serovar entomocidus INA288 but, B. thuringiensis israelensis ONR60A has irregular shaped crystal protein. Toxicity results that serovar entomocidus INA288, serovar aizawai BUN 1-14 and serovar israelensis ONR60A showed toxic to mosquito insects. which was composed of major protein of $130 \mathrm{kDa}$ peptides. B. thuringiensis serovar entomocidus INA288 has $70 \mathrm{kDa}$ and aizawai BUN 1-14 had $69 \mathrm{kDa}$. Conclusion: B. thuringiensis strain had different crystal protein form but had same toxicity.
\end{abstract}

Keywords: B. Thuringiensis, Soil, Leaves

\section{Introduction}

Numerous chemical insecticides have been used to control some insects. While chemical insecticides have knock down effect, they are too expensive harmfull to both humans and the environment. In addition, target insect pests develop biological resistance rapidly especially at higher rates of application. Thus, the increase in pesticidal application to control this pest has urged to researcher to search for biological control alternatives that would be a good component of Integrated Pest Management [1, 32, 33].

Bacillus thuringiensis is a gram-positive, spore-forming bacterium that produce parasporal crystal during the sporulation stage. The crystal is made of one or more proteins toxic to some insect species. Most strains of $B$. thuringiensis produce delta-endotoxin crystal toxic to lepidopteran insect such as moth [2, 28, 29].
The name proposed of Bacillus thuringiensis for a species of bacillus which was isolated from diseased larvae of Mediterranean flour moth Angasta (Ephestia) kuhniella Zell [3]. Later, noted infection of the larvae after the ingestion of the bacillus or its spores, described and named it Bacillus thuringiensis [3, 4]. It isolated the same bacillus from the same insect host [4], which had found earlier. This strain is now maintained as $B$. thuringiensis serovar thuringiensis (serotype $\mathrm{H}-1$ ). They noticed that the vegetative remains of sporulating cells assumed a rhomboid shape [3, 4]. He described this crystalline inclusion in the sporangium of the organism and made further interpretations of the data being accumulated on this bacillus at that time. Neither Berliner nor Mattes attributed those parasporal bodies any role in the the disease process caused by the ingestion of sporalating $B$. thuringiensis [5].

B. thuringiensis is a gram-positive soil bacterium, and 
produce a crystalline inclusion body during sporalation [6, 27, 28]. This parasporal body is composed of proteins termed "delta-endotoxin", and specifically toxic to insects. In addition, B. thuringiensis produce another toxins namely: alpha-exotoxin, beta-exotoxin, and gamma-exotoxin. All of the toxic substances may not be present in the bacterium [7, 20, 21]. In another hand, Krieg [8] has defined various toxic substance produced by $B$. thuringiensis as follow: (a) thermolabile endotoxin; (b) thermostable exotoxin; (c) bacillogenic antibiotic; (d) lecithinase; (e) proteinase.

B. thuringiensis has been studied world wide over the past decades, mainly because this gram-positive bacterium produce significant amount of crystal proteins with toxic activity against economically important insect larvae $[9,18$, 28]. The most attractive characteristics of the B. thuringiensis proteins for insect control are their specificity and high unit activity. Members of non-target insect orders are not susceptible to the potent effects of the lepidoptern-specific and dipteran-specific insecticidal proteins [10, 27, 29]. Most strains of $B$. thuringiensis produce delta-endotoxin crystals toxic to lepidopteran insects such moth [11, 23, 25], But some strains of $B$. thuringiensis produce delta-endotoxin crystals toxic to dipteran insects such as mosquitoes [12, 2224] and blackflies.. Lepidopteran-specific delta-endotoxin are composed $130 \mathrm{kDa}$ proteins [13, 15-17] while dipteranspecific delta endotoxin are composed of several protein [13, 18-20].

Bacillus strains possessing a high larvacidal activity, specific for mosquitoes, from the soil of mosquitoes-breeding site in Israel [11, 25-27]. The objective of the studies to compare B.thuringiensis strains serovar entomocidusI NA288 (soil isolated), serovar aizawai Bun 1-14 (leaves isolated) and israelensisONR60A (standard isolate).

\section{Materials and Methods}

Bacterial stains. The strain of B. thuringiensis used in the present study were $B$. thuringiensis serovar entomocidus INA 288, serovar aizawai BUN 1-14 and israelenis ONR60A (standard isolate).

\subsection{Isolation and Identification}

B. thuringiensis serovar entomocidus INA288 which had been isolated from Indonesia soil, was prepared according to the method [14]. One gram of soil samples was suspended in $9 \mathrm{ml}$ of sterile distilled water and shaken for $5 \mathrm{~min}$. the upper layer of the soil suspension was transferred to a test tube and heated at $80^{\circ} \mathrm{C}$ for $5 \mathrm{~min}$ in water bath to kill non-sporeforming organism and vegetative cells to prepare the sporulated culture, bacteria were grown on nutrient agar $\mathrm{pH}$ 7.2 , at $30^{\circ} \mathrm{C}$ for 4 days. Formation of spores and parasporal inclusion were monitored with a phase-contrast microscope. The culture was scratched on the agar slant as a stock. $B$. thuringiensis serovar aizawai BUN 1-14 which had been isolated from mulberry leaves. Isolates were obtained from mulberry leaves collected in West Java, Indonesia, using the leaf-lift technique $[15,16]$. Leaves were trimmed to fit inside a $100 \mathrm{~mm}$ petri dish. Abaxial leaf surfaces were placed in contact with nutrient agar, and a sterile, per forated stainless steel disk was placed on the leaf sections to ensure maximum contact with the agar. The lid was replaced, and samples were incubated at $30^{\circ} \mathrm{C}$ overnight. To prepare the sporulated culture, bacteria were grown on nutrient agar, $\mathrm{pH} \mathrm{7,0,} \mathrm{at}$ $30^{\circ} \mathrm{C}$ for 4 days. Formation of spores and parasporal inclusion were monitored with a phase-contrast microscope.

\subsection{Morphology of Parasporal Inclusion}

Isolates were examine with a HITACHI S-800 Scanning Electron Microscope (SEM) at a magnification of 10,000x, according to the method presented by [23, 24]. $B$. turingiensis serovar entomocidus INA288 were cultured on $\mathrm{N}$-broth agar at $30^{\circ} \mathrm{C}$ until almost all cells lysed (overnight). The crystal and spores (about $100 \mathrm{mg}$ wet weight) were washed in $10 \mathrm{ml}$ of $50 \mathrm{mMTris}-\mathrm{HCL}(\mathrm{pH} \mathrm{8.0)}$. The final precipitate was resuspended in $1 \mathrm{ml}$ of distilled water, and 20 $\mathrm{ul}$ of the suspension was air-dried on a glass disk (O $10 \mathrm{~mm})$. After the sample was coated with carbon and gold, it was observed and photographed with SEM.

\subsection{Biological Activity}

The strain were examined for their larvicidal against the larvae of the silkworm, Plutella xylostella and Spodoptera litura. The insect cultures were maintained in this laboratory. Toxicity test with the Leppidopteran insect, B. mori, $P$. xyloetella and $S$. litura, were done by introducing ten $3^{\text {rd }}$ intar larvae were fed on an artificial diet dropped with $0.3 \mathrm{ml}$ of the bacterial suspension and rear at $25^{\circ} \mathrm{C}$ for $48 \mathrm{hr}$ to determine mortality. The $B$. thuringiensis isolates were examined for oral insecticidal activity against the insects were prepared by the following procedures. Overnight culture of serovar entomocidus INA288, BUN 1-14 and israelensis ONR60A were grown on $2 \mathrm{ml}$ of nutrient broth at $30^{\circ} \mathrm{C}$ using tube glass. Then, $200 \mathrm{ul}$ of the overnight culture was plating on nutrient agar, reincubated for 4 days at $30^{\circ} \mathrm{C}$. Sporulated cultures were harvested by centrifugation at $10,000 \mathrm{~g}$ for $\min$ at $4^{\circ} \mathrm{C}$. The pellet was washed three times by centrifugation in mMTris-HCL and $1 \mathrm{M} \mathrm{NaCL}$ at $4^{\circ} \mathrm{C}$, the bacterial suspensions were finally suspended in $500 \mathrm{ul}$ of sterile distilled water. The bacteria were also tested against larvae of the mosquitoes, Aedes aegypti, Aedes japonicus and Culex quinquefasciatus. Ten $2^{\text {nd }}$-instar larvae were placed in a test tube containing $10 \mathrm{ml}$ of the spore-parasporal inclusion suspension, respectively, under levels $1 \mathrm{ul} / \mathrm{ml}$. The tubes were kept at $22^{\circ} \mathrm{C}$ for $24 \mathrm{hr}$ without feeding.

\section{Result and Discussion}

In order to identify serovar entomocidus INA288 strains by $\mathrm{H}$-serotype cell with broth, they were dropped to glass slide and the motility of cells was observed under phase-contrast microscope. Since isolate of serovar entomocidus INA288 gave positive reaction in the $\mathrm{H} 6$ serum agglutination test, it was identified as $B$. thuringeisis serovar entomocidus 
INA288. interestingly, entomocidus INA288 produced large cuboidal-form crystals (Figure 1). On the other hand, $B$. thuringiensis serovar aizawai BUN 1-14 a little homology with serovar entomocidus INA288 (Figure 2). Interestingly, B. thuringiensis serovar israelensis ONR60A [23, 24] has irregular shaped crystal protein.

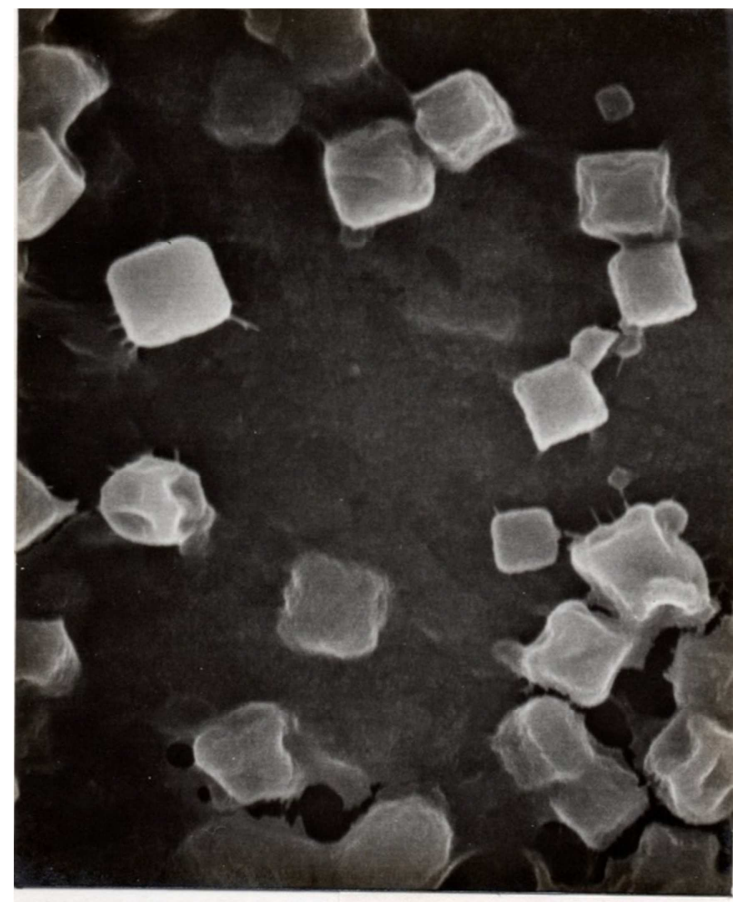

Figure 1. Scanning electron microscopy (SEM) showing spores and parasporal crystal of Bacillus thuringiensis serovar entomocidus INA288. Bar indicates $3 \mathrm{um}$.

B. thuringiensis serovar israelensis ONR60A had mosquitocidal activity, which was composed of major protein of $130 \mathrm{kDa}$ peptides. On the other hand, B. thuringiensis serovar entomocidus INA288 and aizawai BUN 1-14 had mosquitocidal activity, while aizawai Bun 2-1 both did not have. In addition, neither serovar entomocidus original strain nor serovar aizawai IPL had lepidopteracidal activity. SDSPAGE profiles of enotmocidus INA288 crystals indicated that the polypeptide of $70 \mathrm{kDa}$ was dominant, while entomocidus original strain was constituted of 130-65 kDa. However, $B$. thuringiensis serovar aizawai Bun 1-14 was composed of polypeptides of $69 \mathrm{kDa}$, while entomicidus Bun 2-1 was constituted of 130-65 kDa. Interestingly, using antibody of $B$. thuringiensis serovar entomocidus INA288 crystal protein demonstrated that there is cross-reactivity among the parasporal inclusion proteins of $B$. thuringiensis serovar aizawai Bun 1-14, israelensis ONR60A, and fukoukaensis. However, [27] demonstrated that using antibodies of $B$. thuringiensis serovar israelensis ONR60A showed weakly cross-reactivity to serovar jegathesan. Indeed, $B$. thuringiensis serovar jegathesan included cryIVD and showed immunological similarity with anbodies of serovar israelensis. While, entomocidus INA288 contained a novel crystal protein gene cryINA288, on plasmid. In addition, the similarity of amino acid sequence between cryINA288 and cry $4 \mathrm{Aa}$ was $38 \%$. On the other hand, serovar aizawai Bun 114 a little homology with serovar entomocidus INA288 (Figure 2).

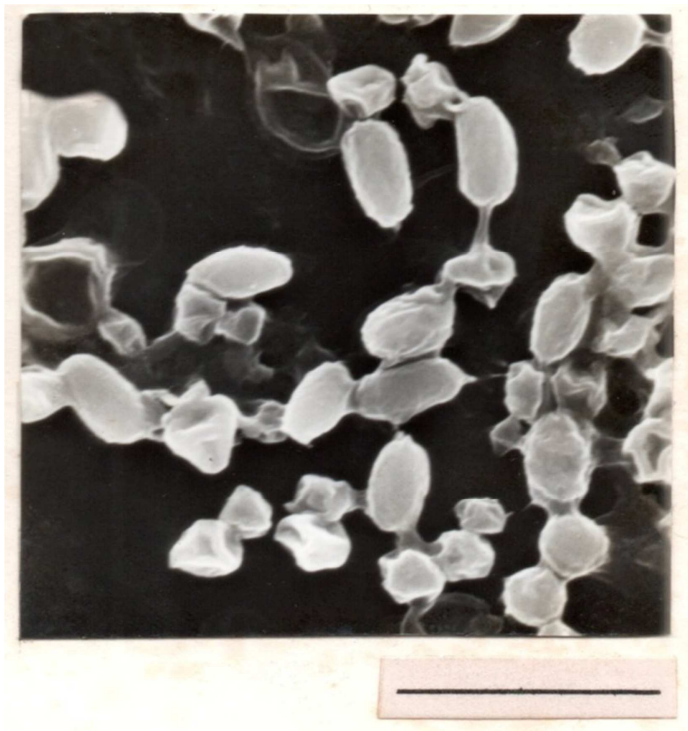

Figure 2. Scanning electron microscopy (SEM) showing spores and parasporal crystal of Bacillus thuringiensis serovar entomocidus INA288. Bar indicates $3 \mathrm{um}$.

\section{Quantitative toxicity test isolate}

The serovar entomocidus INA288, serovar aizawai BUN 1-14 and israelensisONR60A were bioassayed against $4^{\text {th }}$-instar larvae of B. mori, P. xylostella, S. litura, A. japonicas, A. aegypti and C. quiquefasciatus. Respectively, serovar entomocidus INA288, aizawai BUN 1-14 showed not toxic activity against latter 3 former lepidoteran species, while serovar entomocidus INA288, aizawaiBUN1-14 and israelensis ONR 60A had the toxicity against latter 3 dipteran species (A. aegypti, A. japonicas and C. quinquefasciatus) (Table 1). However they had differences form crystal protein, but they had unique as insecticidal to control the same orders (Mosquitoes).

Table 1. Toxic activity of three B.thuringiensis strains against some insect species.

\begin{tabular}{llllll}
\hline \multirow{2}{*}{ Strain } & \multicolumn{2}{l}{ Lepidopteracidal } & & Dipteracidal \\
\cline { 2 - 6 } & $\boldsymbol{B , \boldsymbol { m } ,}$ & $\boldsymbol{P . x .}$ & S.l. & A.j. & A.a. \\
\hline Serovar entomocidus INA288 & - & - & - & + & + \\
Serovar aizawai BUN 1-14 & - & - & - & + & + \\
Serovar israelensis ONR60A & - & - & - & + & + \\
\hline
\end{tabular}

B, m: Bombyx mori, P.x: Plutella xylostella, S.1: Spodoptera litura

A.j: Aedes japonicas, A.a: Aedes aegypty, C.q: culex quinquefasciatus 


\section{Conclusion}

In the search for potential alternatives to the application of B. thuringiensis serovar israelensis ONR60, entomocidus INA288 and aizawai BUN 1-14 isolation of novel mosquitocidal strains. The crystal proteins form of $B$. thuringiensis serovar entomocidus INA288 has cuboidal shaped, serovar aizawai BUN 1-14 has homology shaped ones and B. thuringiensis serovar israelensis ONR60A has irregular., which was composed of major protein of $130 \mathrm{kDa}$ peptides. B. thuringiensis serovar entomocidus INA288 has $70 \mathrm{kDa}$ and aizawai BUN 1-14 had $69 \mathrm{kDa}$.

\section{Acknowledgements}

The author wishes to express his sincerely gratitude to his adviser, Dr. TOSHIHIKO Iizuka, Professor of Bioscience at the Faculty of Agriculture, Hokkaido University. Sapporo, Japan for his excellent guidance, suggesting, constant encouragement, and critical review in the preparation of this article.

\section{References}

[1] Brar, S. K., Verma, M., Tyagi, R. D. and Valero, J. R. 2006. Recent advances in down streamprocessing and formulations of Bacillus thuringiensis based biopesticide. Process Biochem, 41(2): 323-342.

[2] Sanahuja, G., Banakar, R., Twyman, R. M. Capell, T. and Christou, P., 2011. Bacillus thuringiensis: a century of research, development and commercial application, Plant Biotechnology. J., 9: 283-300.

[3] Berliner, E. (1915). Oberdieschalaffsucht der mehlmottenraupe (Ephestiakuhniella Zeller) und ihrenerregerBacillusthuringiensis n. sp. Zangue. Entomol. 2: 29-56.

[4] Mattes, O. (1927). Parasitarekrankheiten der mehnottenlarvaen und versucheoberihreverwndbarkeitalsbilogischebecampfungismitt el. (Zuheich lire beitragzurzytologie de bacgerien). Gesell $\mathrm{f}$. beford, gedam, naturw. Sitzber (Marbnog) 62: 381-417.

[5] Rizali, A., Shin-ichiro Asano, Ken Sahara, Hisanori Bando, Bibiana W, Lay, SugyoHastowo and Toshihiko Iizuka.(1998). Novel Bacillus thuringiensis serovar aizawai strains isolated from mulberry leaves in Indonesia. Appl. Entomol. Zool. 33 (1): 111-114.

[6] Bulla, L. A., faust, R. M., Andrews, R. and Goodman, N. (1985). Insecticidal bacilli, pp. 185-209. In: the Moleculer Biology of the Bacilli, Volume II. D. A. Dubnau (ed.). Academic Press, New York.

[7] Heimpel, A. M. (1967). A critical review of Bacillus thuringiensisBerl. And other crystalliferous bacteria. Ann. Rev. Entomol. 12: 287-322.

[8] Krieg. A. (1961). Bacillus thuringiensis Berliner. In disease caused by certain sporeforming bacteria. Heimpel and Angus (eds.). 21-67.
[9] Delucca, A. J. II, Simonson, J. G and Larson, A. D. (1981). Bacillus thuringiensis distribution in soils of the United States. Canadian J. Maicrobiol. 27: 865-870.

[10] Dulmage, H. T. (1992). Insecticidal activity of Bacillus thuringiensis and their potential for pest control in Microbial control for pests and plant diseases and plant diseases 19701980 (ed. H. D Burges). Acad. Press. N. Y. PP.

[11] Golberg, L. J. and Margalit, J. (1977). A bacterial spore demonstrating rapid larvicidal activity against Anopheles sergentii, Uranotaeniaunguiculata, Culexunivitattus, Aedesaegypti and Culexpipiens, Mosq. New 37: 355-358.

[12] Pfannenstiel, M. A., Ross, E. J., Kramer, V. C. and Nickerson, K. W. (1984). Toxicity and composition of protease-inhibited Bacillus thuringiensis var. israelensis crystal. FEMSMicrobio. Lett. 21: 39-42.

[13] Hastowo, S., Lay, B. W. and Ohba, M. (1982). Naturally occurring Bacillus thuringiensis in Indonesia. J. Apply. Bacteriol. 73: 108-113.

[14] Iizuka, T., Ishino, M. and Nakajima, T (1982). Comparative morphology of Parasporal crystal and characterization of plasmid DNA from various subspecies of entomopathogenic bacteria, Bacillus thuringiensis. J. Fac. Agric. Hokkaido Univ. 13: 423-431.

[15] Asano, S., Bando, H. and lizuka T. (1993). Amplification and identification of cryII genes from Baccilus thuringiensis by PCR procedures. J. Seric. Sci. Jpn. 62: 223-227.

[16] Asano, S. (1996) Identification of cry gene from Bacillus thuringiensis by PCR and isolation of unique insecticidal bacteria. Mem. Fac. Agric. Hokkaido Univ. 19: 529-563.

[17] Baba, F., Asano, S. and Iizuka T. (1990). Purification of crystals from Bacillus thurigiensisby using Percoll. J. Sci. Jpn 59: 487-489.

[18] Balarman, K., Hoti, S. L. and Manonmani, L. M (1981). An Idigenous virulent strain of Bacillus thuringiensis, highly pathogenic and specific to mosquitoes. Current Science 50: 199-200.

[19] Burges, H. D. 1981. Microbial control of pest and plant disease. 1970-1980. Academic Press. 949 pp.

[20] Burges, H. D. and N. W. Hussey, 1971. Microbial control of insects and mites. Academic Press. 876 pp.

[21] Bulla, L. A., Jr., Kramer, K. J. and Davidson, L. I. (1977). Characterization of the entomocidal parasporal crystal of Bacillus thuringiensis. J. Bacteriol. 130: 375-383.

[22] Held, G. A., Kawanishi, C. Y. and Huang, Y. -S. (1990). Characterization of the parasporal inclusion of Bacillus thuringiensis subsp. Kyushuensis. J. Bacteriol. 481-483.

[23] Iizuka, T. and Yamamoto, T. (1984). Serological properties of the mosquitocidal protein of Bacillus thuringiensis and the morphology of its parasoral crystal. J. fac. Hokkaido Univ. 62: 98-114.

[24] Iizuka, T., Sasaki, J., Asano, S. and Bando, H. (1995). Comparative studies on isolation and identification of Bacillus thuringiensis. Biotechnology and Enviro. Benefits, Vol. I, 143-153.

[25] Ishiwata. S. (1901). On a kind of severe flacherie (sotto disease). Dainihon Sanshikaiho 114: 1-5. 
[26] Kalman, S., Kiehne, K. K., Libs, J. L. and Yamamoto, T. (1993). Cloning of novel cryIC-type gene from a strain Bacillus thuringiensis subs. Galleriae. Appl. Enviro. Microbio. 59: 1131-1137.

[27] Kawalek, M. D., Benjamin, S., Lee, H. L. and Gill, S. S. (1995). Isolation and identification of novel toxin from a new mosquitocidal isolate from Malaysia, Bacillus thuringiensis subsp. Jegathesan. Apl. Enviro. Microbiol. 2965-2969.

[28] Kim, K. H., Ohba. And aizawa. K. (1984). Purification of the toxic protein from Bacillus thuringiensis serotype 10 isolate demonstrating a preferential larvicidal activity to mosquito. J. Invertebr. Pathol. 44: 214-219.

[29] Ohba, M. andAizawa, K. (1986). Insect toxicity of Bacillus thuringiensis isolated from soils of Japan. J. Invertebr. Pathol. 47: $12-20$.

[30] Padua, L. E., Ohba, M. and Aizawa, K. (1984). Isolation of a Bacillus thuringiensis strain (serotype 8a:8b) highly and selectively toxic against mosqouito larvae. J. Invertebr. Pathol. 44: 12-17.
[31] Rejesus, B. M. and A. Sayaboc, (1990). Management of DBM with Apanteles plutellae prosfects in the Philippines. Paper presented in the second International Workshop on Diamondback Moth Management. Dec. 10-15, 1990. Tainna, Taiwan. 17 pp.

[32] Shorey, H. H. and I. M. Hall.(1962). Effect of chemical and microbial insecticides on several insect pests of lettuce in southern California. J. Econ. Entomol. 56: 169-174.

[33] Yu, Y. -M., Ohba, M. and Gill, S. S (1991). Characterization of mosquitocidal activity of Bacillus thuringiensis subsp. Fukuokaensis crystal proteins. Appl. Enviro. Microbiol. 10751081.

[34] Zhang, Y., Ku, Z., Chan, Z., Xu, B., Yuan, F., Chen, G., Zhong, T. and Ming, G. (1984). A new isolate of Bacillus thuringiensis possessing high toxicity against the mosquitoes. Acta MicrobilogicaSinica 24: 320-325. 